\title{
Traumatizing Images of Belfast in Mary Costello's Novel Titanic Town
}

\section{Introduction}

This chapter focuses on mental images of traumatic experiences in Mary Costello's semi-autobiographic novel Titanic Town, published in 1992. The action is set in Belfast in the 1970s, during the most violent period of the Northern Irish conflict somewhat euphemistically referred to as the Troubles. In the novel, the city of Belfast is described as a place in which "trauma is the shared reality" (Costello 1992: 227). While the plot is inspired by the author's adolescence in Republican West Belfast, the book was actually written in Melbourne, where Costello has lived since her emigration to Australia in 1981 (Caterson 1994: 6). The action is told from the perspective of Annie McPhelimy, a young girl growing up in the midst of the Troubles with her younger siblings Sinead, Thomas, and Brendan. The novel shows the different ways in which the city, as the center of violence, enters the life of children and adolescents. Its focus lies on the traumatic images that are generated in the protagonist's mind.

In the following chapter, a traumatizing image or picture will be conceived as "a picture of the mind" (2005: xiv). According to W. J. T. Mitchell, a mental picture is "the imagination or memory of an embodied consciousness" in which "a state of affairs" is projected (2005: xiv). Mitchell's perception of a picture as a mental image can be seen as an extension of Heffernan's reading of an image as "a verbal representation of a visual representation" (1993: 3). Mitchell explains that the word "image" is "notoriously ambiguous" as it can denote both a "physical object" such as a painting or a sculpture, or a "mental, imaginary entity," which he calls a "psychological image" (2005: 2). This mental image he sees as the "visual content of dreams, memories and perceptions" (2005: 2). Mitchell further states that a picture does not present the world as is it, but the world as it is "conceived and grasped" by its observer (2005: xiv).

Apart from Mitchell's "picture of the mind," Kevin Lynch's concept of "mental maps" (1983) will guide our analysis of Titanic Town. Lynch's "mental maps" can be compared to Mitchell's "pictures of the mind" (1983: 1-2). However, they differ from Mitchell's concept in the sense that they specifically refer to the cognitive perception of urban space. According to Lynch, citizens have personal "mental images" of their environment, which are "soaked in memories and meanings" (1983: 1-2). In the context of Costello’s novel, the traumatic “mental

Ә OpenAccess. () 2020 Stephanie Schwerter, published by De Gruyter. (cc) BY-NC-ND This work is licensed under the Creative Commons Attribution-NonCommercial-NoDerivatives 4.0 License. 
images" are linked to particular areas of Belfast, which in the protagonist's mind are connected with traumatizing experiences.

Through the protagonist's juvenile point of view, Costello presents the Northern Irish conflict from an innovative angle. Given the unusual perspectives from which the novel portrays the troubled life of Belfast, Viktor Shklovsky's theory of defamiliarization will serve as a lens through which we shall explore Annie's "mental images." Shklovsky argues that in order to achieve an alienating vision of a particular state of affairs, it has to be presented in a "strange" - that is, in an unhabitual - way. In the case of Titanic Town, this alienating perspective is achieved through the perception of the Troubles through the eyes of a young girl. Annie's state of mind, shaped by a warlike situation, serves as a filter through which these violent incidents become transformed into personal mental images. In Titanic Town, the verbal representation of traumatic events echoes the visual picture of the consequences of political violence. In the following, we shall explore the young protagonist's mental images of troubled Belfast, focusing on Annie's reading of urban space, her individual perception of what is considered to be normality in a war-torn environment, as well as her cognitive picture of specific traumatizing situations.

In his seminal book The Body Keeps the Score, the psychiatrist Bessel van der Kolk claims that trauma is not "just an event that took place sometime in the past" but "the imprint left by that experience on mind, brain, and body" (2014: 21). He further explains that traumatized individuals feel suddenly "hijacked by images, feelings, and sounds from the past” (2014: 40). Van der Kolk draws attention to the fact that one of the most effective ways to access one's inner world of feelings is through writing. He claims that trauma victims who put their emotions into words experience an intense feeling of peace after having mentally returned to painful events of the past (2014: 238).

In this sense, it is not unlikely that in Titanic Town, Costello attempts to overcome her own traumatic experience of growing up in West Belfast during the Troubles. The writing of a semi-autobiographical memoir seems to allow her to revisit disturbing events of her childhood. In the preface to her book, she establishes a clear connection between herself and the teenage protagonist:

Along with thousands of my fellow citizens I was witness to the absurd as well as the despicable and this account is drawn partly from memory and partly from imagination. I don't pretend that Titanic Town contains all the facts of my life and times, but Annie McPhelimy is certainly part of me (Costello 1992: author's note, n.p.).

In an interview, Costello states that while living in Belfast, she was unable to write about her traumatic experiences: "When you're there, you get caught up 
in what's going on. You're so absorbed in it and appalled by it. It fills you with such despair when you see the brutality and the killing that nothing is worth doing, certainly not writing a crappy book about it” (Caterson 1994: 6). Only after having gained an emotional and mental distance in relation to the place where sectarianism and political violence were part of everyday life could she detach herself from the past and write about her experience. According to Aleida Assmann, "images and writing have been linked with memory ever since Antiquity" (1999: 210). In the light of Assmann's statement, we could argue that Costello attempts to overcome painful events by means of writing and through the exploration of traumatizing images. Mitchell claims that trauma is supposed to be "unrepresentable in word and images" (2005: 60). However, he states that trauma is increasingly represented in literary and visual ways. Mitchell underlines that some works of literature or art intend to transmit trauma as directly as possible in order to "rub" the spectator's or reader's "face in the unspeakable and unimaginable" (2005: 16). In this light, we may say that in Titanic Town, Costello depicts the trauma suffered by young people living in Belfast during the Troubles through the protagonist's teenage vision of her violent environment, while her own childhood trauma serves as a source of inspiration.

\section{Interpreting Belfast's territoriality}

Since the outbreak of the Northern Irish conflict in 1968, a remarkable body of literature on the situation in Northern Ireland has been produced. To date, more than 800 novels and short stories dealing with the impact of political violence on Northern Irish society have been published (Kennedy 2005). Most of them are set in Belfast and depict the traumatic influence of the conflict on the city's inhabitants. As the urban center of the Troubles, Belfast represents a microcosm of Northern Ireland in which the region's sectarian problems are found in their most concentrated form. Even today, numerous peacelines, ${ }^{1}$ about 300 murals, and several kilometers of curbstone paintings in the colors of the Union Jack or the Irish Tricolor still separate Catholic and Protestant territories from each other. Belfast's urban space resembles a patchwork of religiously segregated areas, something that contributes to making the city a meto-

1 The so-called peacelines occur in different forms and shapes. According to the findings of the Interface project, the following barriers dividing Catholic from Protestant areas can be found: 20 mesh fences, 16 steel fences, 4 palisade fences, 13 walls, 14 walls with a fence above, 5 walls with a gate, 12 gates and 13 buffer fences ("Interface Barriers, Peacelines and Defensive Architecture"). 
nym for division and conflict in its various literary representations (Shirlow and Murtagh 2006: 61-81).

The action of the novel takes place in Republican West Belfast against the backdrop of the Women's Peace Movement, in which Bernie McPhelimy - Annie's mother - becomes one of the leading figures. This fictional movement is modeled on the Peace People, a peace initiative founded by Betty Williams and Mairead Maguire in the mid-1970s. The organization was started up by a group of local women who initially protested against the shooting between the security forces and the IRA in their area. Eventually, their initiative turned into an internationally supported peace movement for which Williams and Maguire received the Nobel Peace Prize in 1976. It is likely that Costello's interest in the Peace People springs from the fact that her own mother was involved in the organization (Kennedy-Andrews 2003: 189).

Whereas Bernie McPhelimy becomes a peace activist, her daughter Annie tries to live the "normal" life of a teenager between school and her various love interests. The novel's focus of attention lies less on the world of politics than on the concerns of a teenage school girl, who has to deal with, as Elmer Kennedy-Andrews puts it, "a mother who has taken to both politics and Valium [...] a shortage of discos and boyfriends, not to mention the terrors of ' $O$ ' and ' $A$ ' levels" (2003: 189). While the story is told in a rather linear way at the beginning of the book, towards its end, the narrative mode becomes more and more impressionistic. The disruptive manner of narration echoes the way in which trauma influences an individual's body and mind. Van der Kolk explains the effect of trauma as follows: "trauma is primarily remembered not as a story, a narrative with a beginning, middle and end, but as isolated sensory imprints: images, sounds, and physical sensations that are accompanied by intense emotions, usually terror and helplessness" (2014: 70). Thus, it could be argued that in her writing, Costello imitates the succession of images and sensations that haunt the mind of a mentally wounded person.

Gerd Hurm states that "fictional city images" are shaped "by the particular issues chosen for treatment” (1991: 9). In this sense, Belfast receives a specifically teenage perspective due to Annie McPhelimy's viewpoint. In order to realistically render the protagonist's mental picture of West Belfast, the author chooses a first-person narrator. The space in front of the family home is described in a detailed way and takes on the appearance of a battlefield. Whereas the political violence restricts Annie's movements through Belfast's urban space, the bedroom window offers an ideal lookout from which she is able to observe the interactions of the security forces and the paramilitaries: 


\begin{abstract}
Violence alone enlivened my girlhood, for I was allowed out only to go to school and mass. But from my bedroom window, under a ceiling black with night and creeping mould I could see the goings-on. The boys and the Brits, the RUC. The dim, indistinguishable figures crawling damply through the neglected gardens, or running in cautious relays across the roads. And the sky above all of it, clear and brittle with stars, though more often clouded and changeful, fitfully illuminated by a dangerous moon. The moon could be a killer: a black balaclava an essential accessory. The black balaclavas of the IRA. (Costello 1992: 3-4)
\end{abstract}

Through the eyes of the protagonist, violence is clearly presented as the key element of her youth. The territory in front of the family's house takes on the form of a battlefield. The dark light and the indistinguishable characters from antagonistic political sides create an alarming atmosphere. Images of danger connected to dilapidation render Belfast an unpleasant and frightening place.

In the context of the given scene, Kevin Lynch's concept of "mental maps" provides a helpful device to understand Annie's interaction with her violent environment. Lynch draws attention to the importance of cognitive geography in the interpretation of an urban complex by its inhabitants. A "mental map" is created in the observer's mind through the subconscious selection of specific elements of the city, which for him or her contain personal meanings. In the above-mentioned scene, the reader enters the protagonist's mind and is confronted with Annie's personal "mental map" of Belfast. This cognitive representation of her area is dominated by dark and menacing images, while positive aspects of the city are entirely absent. Due to the disturbing experiences she has lived through, Annie seems to be incapable of integrating cheerful impressions and memories into her cognitive map of Belfast. Speaking in Mitchell's terms, her "psychological image" of the city is shaped by her individual interpretation of, and negative perspective upon, Belfast's sectarian geography.

Lynch underlines the importance of mental maps in the process of "way finding," and explains that the "environmental image" held by an individual is "used to interpret information and to guide action" (1983: 4). In the same vein, Liam Kennedy argues that places are charged with "emotional and mythical meanings; localized stories, images and memories” (2003: 27). For this reason, they can provide meaningful cultural and historical bearings for "urban individuals" (2003: 72). This applies in particular to the inhabitants of Belfast, who interpret their environment according to existing boundary markers such as peacelines, murals, flags, and curbstone paintings. A. T. Q. Stewart even goes so far as to claim that local knowledge is essential for people living in Northern Ireland to such an extent that they carry an almost innate "religious geography" in their mind (1977: 180).

Annie is guided through the city's urban maze with the help of her individual cognitive geography. On her personal mental map, the area in which she lives 
with her family is clearly marked out as Catholic territory, belonging to Republican West Belfast. The protagonist refers to the people who creep through the garden at night as the "boys," "the Brits," and the "RUC." While with the "RUC" she refers to the Royal Ulster Constabulary, the police force in Northern Ireland, she uses the term "the Brits" to allude to the British Army. Belonging to the British establishment, both organizations were seen by Northern Irish Catholics as instruments of the British "colonizer" who merely acted in the interests of the Protestant community and therefore were regarded as enemies. Through her choice of words, Annie not only expresses her disapproval of the presence of the RUC and the British army in her front garden, but also presents both organizations as intruders who are not welcome on Catholic territory.

Referring to the IRA, on the other hand, she uses the almost endearing term "the boys." The scene shows that even as a young girl, Annie is tuned into the sectarian discourse of her community. Her utterance illustrates her awareness of Belfast's sectarian geography and her ability to interpret the violent events happening in her direct environment along ethno-religious lines. The perception of the IRA as the defenders of the Catholic community becomes further illustrated through the image of the "dangerous moon" which turns into "a killer." With its bright light, the moon reveals the identity of individuals present at night in the garden. In this way, it presents a particular danger to IRA men: as members of a counter-hegemonic paramilitary organization, it is in their interest not to be recognized. Therefore, a "black balaclava” becomes an "essential accessory" in order to remain unidentifiable. Through the description of the moon as a threat to "the boys," the reader is yet again reminded of Annie's positive attitude towards the IRA and her perception of the paramilitary organization as the protector of the area. On Annie's "mental picture” of her area, the IRA shows as a positive element. Thus, using the words of Mitchell, the world is not represented in an objective or neutral way, but as it is "conceived and grasped" by its observer (2005: xiv).

The scene continues with a further traumatizing image. It is not only the nightly events on the ground that endanger the young protagonist's life, but also the goings-on in the sky. Annie's account of army surveillance from the air presents an additional source of anxiety: "The army began to use helicopters with searchlights. Powerful. They would light up my room like broad daylight as I crouched below the window, not wishing to be mistaken for a sniper” (1992: 4). The fact that Annie is afraid of being taken for a gunman can be seen as a reaction triggered by the traumatizing influence of the omnipresent political violence on Belfast's population. Whereas in a peaceful environment this kind of consideration would seem absurd, in West Belfast during the Troubles, however, any person behaving in a supposedly suspicious way could run the risk of being mis- 
taken for a sniper. On Annie's "mental map" it is not only the ground that is invaded by the British army, but also the space above it. The protagonist's comment emphasizes that even her own house does not provide shelter from the violence being acted out on the streets.

As the action continues, the family becomes intimidated by their neighbors due to Bernie's peace initiative. As the head of the Women's peace movement, Bernie tries to fight for the end of the daily shooting between the IRA and the security forces in the area. This means that she has to get in contact with British government representatives as well as with the IRA. For several of her neighbors, her negotiations with the British government are seen as a betrayal of the Republican community, as interacting with British politicians is interpreted as being tantamount to turning against the IRA. For this reason, the family home is violently attacked, and Annie's brother, Thomas, is injured by a thrown brick. After this incident, the parents decide to move out of the area in order to avoid further aggression. Despite the traumatizing events Annie lived through in West Belfast, she is still emotionally attached to the area in which she spent part of her childhood:

\footnotetext{
My tears salted the champ. I didn't want to leave Bunbeg. I loved Bunbeg. And now it was all ballsed up. I knew for definite now that life wasn't fucking worth living. Nothing would ever be normal again. It emerged later that the parents had been down to see the Housing Executive, who would attempt to find us somewhere suitable as quickly as possible. For the moment, we would have to stay where we were. But we could rest assured, we were on the top of the Emergency Housing Intimidation list. (Costello 1992: 226)
}

For Annie, the worst thing about being intimidated by her neighbors is the fact that her family is attacked on territory which, on her cognitive geography of Belfast, signifies "safe ground." The McPhelimy family feels endangered not only by the British security forces but also by members of their own community. The sensation of being under attack from both sides creates a particularly destabilizing situation for the teenage protagonist. Ralph Willet's perspective on cognitive perceptions of city space is again helpful. He claims that a city is always an "observed and imagined environment” (1996: 19). In the given scene, Annie's “observed" and "imagined" environments clash. While she imagines Bunbeg as a safe haven, she has to realize that the situation has changed and now she and her family live on hostile ground. This state of affairs explains her inability to integrate positive aspects of Belfast into her personal mental map: even Bunbeg, the area she used to love, is now "totally ballsed up", leading Annie to the conclusion that life is not worth living. Due to Annie's interpretation of the city through the lens of her cognitive geography, Belfast becomes represented on her "picture of the mind" in the darkest colors. 


\section{Depiction of normality in war-torn Belfast}

In the following, we shall concentrate on what Annie McPhelimy perceives as normality in her violent environment. Mitchell states that every history "is really two histories": whereas the first kind of history is the one of "what actually happened," the second one is "the history of the perception of what happened" (2011: xi). Mitchell further explains that the first kind of history focuses on the facts and figures, while the second concentrates on the images and words defining the framework within which those facts and figures make sense (2011: xi). In the context of Titanic Town, "the history of what actually happened" is the Northern Irish conflict, with its death rate at its peak in the 1970s, and the numerous clashes between the two communities and the government forces. ${ }^{2}$ The "history of the perception of what happened" is Annie's tale of her youth in West Belfast perceived from her individual perspective.

With the intention of presenting the traumatic events for herself and the reader in a bearable way, Costello employs humor and irony as literary means. Through the use of humor, the author does not aim to downplay the gravity of the events, but rather wishes to sharpen the reader's view of the situation. According to Bakhtin, laughter does not "deny seriousness but purifies and completes it" (1984: 112). The following humorous scene demonstrates the absurdities of everyday life in troubled Belfast as perceived by the teenage protagonist. Here, Annie describes a "typical" Saturday morning in West Belfast in the 1970s:

For the fortieth time that day army vehicles rumbled past the house causing the nest of Tupperware bowls to shudder one inside the other. It was Saturday and the fine weather brought the young fellas out in force. There had been intermittent riots all morning and still the odd stone or chunk of paving bounced off the armour plating of patrolling Saracens. But it was basically the lunch-hour lull. (Costello 1992: 222)

Annie's "mental picture" of the "lunch-hour lull" might seem surprising to the reader. It takes on an ironic dimension, as the presence of army vehicles and the flying chunks of paving would appear as disturbing in a peaceful environment. Annie, however, sees the situation as a relief from the omnipresent violence. The army vehicles are regarded by her as a mere everyday occurrence, which is so common that the only thing she feels worth mentioning is the fact

2 The most violent period of the Troubles was the period between 1971 and 1976, with 1752 killing in six years (171 in 1971, 479 in 1972, 253 in 1973, 294 in 1974, 260 in 1975 and 295 in 1976). After 1976, the death rate declined with 111 killings in 1977, 82 in 1978 and 121 in 1979 (Sutton http://cain.ulst.ac.uk/sutton/chron/index.html). 
that they make the kitchen cupboards shake. Annie's illustration of the "peaceful" Saturday morning is given a humorous overtone when she mentions that the good weather encourages young men to come out and engage in rioting in front of her window. As Annie is only allowed to leave the house in order to go to school and to church, her possibilities of getting in contact with boys of her age are fairly limited. The fact that the majority of schools in Northern Ireland are either all-girl or all-boy restricts her chances of finding a boyfriend even more. Considering that outside the two institutions, it is almost impossible for Annie to encounter young men, the riots in front of her window are a welcome occasion to meet them, or at least to look at them. According to Bakhtin, laughter caused by absurd situations amounts to "the word's second truth" (1984: 112). Thus, we could say that through the subversive humor employed in the scene, the novel attracts attention to the erosion of normal daily life due to the Northern Irish conflict.

For Annie, the Troubles signify a considerable constraint on her personal autonomy: British soldiers, police, and the IRA - all male representatives of the patriarchal social order - are in control not only of her community but also of her private sphere. The imminent danger of being attacked by the paramilitaries or arrested by the security forces limits Annie's freedom of movement within the city. Through a comical depiction of parental restrictions imposed on young females, Costello renders the dangers of political violence for Northern Irish women during the Troubles by means of humor. In the following passage, Annie describes a "normal" evening out for a teenager living in Belfast in the 1970s:

\begin{abstract}
A typical night out in Titanic Town. There were the parents to be persuaded. We would not be late, we would not drink, not smoke or indulge in impure acts. We would not be set up by gangs of rapists, bag-snatchers or drug-pushers. Nor would we get arrested, or involved in a riot or related incident. We would not travel on a bus which would be hijacked. We would not place ourselves in the path of any bomb, bullet or simple incendiary device. We would not be induced to get into cars full of paramilitaries, especially not if they clapped hands over our mouths and placed bags over our heads. We would not, in short, be assassinated. We would not be persuaded to give up our studies and run away to join the IRA. My parents between them thought of everything. Hilda's mother was merely anxious that we should remember to take an umbrella. (Costello 1992: 270)
\end{abstract}

Annie's comment receives a comic dimension through the juxtaposition of the "dangers" parents of teenager are afraid of in "normal circumstances" - such as their children smoking, drinking, or having sex - and the dangers feared by Mrs. and Mr. McPhelimy. Noël Carroll has claimed that the key to "comic amusement" is the deviation from a presupposed norm. For that reason, the in- 
congruity created through a digression from an assumed standard serves to generate laughter (Carroll 2014: 17). Against the background of the given scene, we could say that Mrs. and Mr. McPhelimy's concerns depart significantly from more typical parental worries. The irony of the situation is, however, that the dangers feared by Annie's parents are not imaginary, but real. In working class Belfast in the 1970s, buses were regularly hijacked, burned, and used to build barricades. In the same way, bombs, shootings, and stray bullets were everyday occurrences. Abductions were also frequent and young people were prone to be recruited by the paramilitary organizations in their community. According to Vivian Mercier, humor springs from the absurd, which is laughable because it is "untrue or irrational or, at the very least, exaggerated" (1962:1). The humorous counterpoint is, however, provided by Hilda's mother, who is only concerned about potential rain. Through Annie's defamiliarizing perspective, the reader perceives the city from a different angle and becomes aware of the danger of everyday life in Belfast in the 1970s.

In Troubles novels, Belfast is frequently referred to as "Titanic Town.” In this context, the term has to be read on different levels. First and foremost, it refers to the fact that the Titanic was built in Belfast. As Harland and Wolff, the shipyard in which the Titanic was constructed, almost exclusively employed Protestant workers, the ship is frequently used as a symbol for Protestantism, and in a larger sense, for Protestant domination of Belfast's Catholic community. A further connotation of the Titanic is the sinking of the ship. In this sense, the Titanic is repeatedly used to allude to the "sinking of Belfast." Thus, the city becomes portrayed as a place in which survival is impossible, in particular for members of the Catholic community. Through the dark imagery evoked by the Titanic, Costello alludes to death and decline despite the humorous tone in which the "typical night out" is narrated.

\section{Images of political violence}

Shklovsky claimed that in order to attract attention to societal shortcomings, the "habitual" has to be represented in an unusual way: "The purpose of art is to impart the sensation of things as they are perceived and not as they are known. The technique of art is to render objects 'unfamiliar', to make forms difficult, to increase the difficulty and length of perception” (1965: 3). Following Shklovsky's theory, we can say that Titanic Town draws attention to the consequences of sectarianism - specifically, traumatizing events generated by political violence - through the alienating perspective of the young protagonist. Annie's perception of the Troubles differs considerably from the habitual readings of the 
Northern Irish conflict, usually conveyed through an adult, frequently male, point of view.

In the following paragraph, the narrator describes a particularly traumatizing situation. As mentioned previously, Annie's brother Thomas is badly wounded by a brick when the family home is attacked by the neighbors. When Annie perceives her brother's injury, the image of the wound turns into a mental picture. In Maurice Halbwachs's words, Annie's memories of the scene become "reduced to a series of successive pictures" (Halbwachs 1992: 55):

Once inside I saw the wound for the first time under the light. It was wide and deep and gory; the red of flesh, the white of bone. Flesh of my flesh. Thomas was very pale, I imagined the blood draining from his head, pouring out of the wound, running down over his sky-blue shirt and metal buttons. I snapped. I screamed and screamed and screamed. It rose and filled the house. It reached outside and filled the street. Like Mrs French's siren I could be heard all over Andersonstown, down the Falls, across the bogs, over Belfast Lough. One of the primal screams. But it wasn't enough. I broke away from Rosaleen who was trying to calm me; I rushed into the hall, threw open the door again and screamed in the face of the crowd. (Costello 1992: 254)

Even if Annie's glance at Thomas's wound takes only a few seconds and could be compared to a "snapshot of a specific moment" (Mitchell 2005: XVII), its subsequent effect is rendered almost in slow motion. The extended description of Annie's reaction to the event underlines the traumatizing influence of the omnipresent violence. The haunting image of her brother's split-open head lets Annie imagine Thomas's blood draining from his body. She sees her brother already dead and mentally connects Thomas's blood to her own. Considering her brother as "flesh of my flesh," she feels personally wounded by her neighbors' attack. Through the biblical image "flesh of my flesh, blood of my blood," Costello subversively points at the costs of the Northern Irish conflict, often interpreted as an ethno-religious conflict.

Annie expresses the horror felt in the situation through a scream travelling beyond the boundaries of the city, reaching "across the bogs over Belfast Lough." In her cognitive picture of the situation, the volume of her scream is not only amplified, but also prolonged. The extended scream directed at the crowd highlights the trauma experienced by the protagonist. In Annie's narration of the events of her childhood, her mental representation of the scene could be compared to a photograph providing a momentary glimpse of a past event. Assmann has argued that in traumatizing situations, "images arise in memory especially in those areas that cannot be accessed by verbal procession" (1999: 209). Annie's scream communicates her inability to put her traumatizing experience into words. Words become replaced with images of the situation and 
remain engraved in her mind. Through the teenage protagonist's perception of the situation, the author depicts the Northern Irish conflict in a non-habitual way and thus, to use Shklovsky's words, manages to "make it strange" (1965: 3). The defamiliarizing view of the Troubles intends to encourage the reader to reflect on the impact of political violence on Belfast's youth.

The last chapter of the book functions as a postscript narrated from Annie's perspective as an adult woman. The following lines are the closing lines of the book:

For the cause, for queen and country, or peace, with justice or at any price. For there will be no surrender, fuck the pope and queen both the same. Sons, sisters, fathers, daughters, husbands and brothers will not be grudged, though they go out to break their strength and die. We will not give an inch and shall not be moved, till the last drops of blood, orange, green, run down the street, through our four green fields, one of them in bondage, to mingle with the rivers of ceaseless rain, seep into the brown sucking bog, and piss, peacefully at last, out into Belfast Lough, in the wake of the Titanic. (Costello 1992: 340)

In the last lines, dark images are created through the quotation of slogans from both political sides. While "no surrender" and "not an inch" are slogans used by the Protestant community to underline their determination to remain on the island, "four green fields" refers to an Irish nationalist folksong. "Fuck the Queen" and "Fuck the Pope" were slogans used by militant Catholics and Protestants, respectively, expressing their dislike of the opposing community. Both slogans are ingrained in Belfast's urban space, as they appear on numerous walls in the form of the acronyms FTQ (for "Fuck the Queen") and FTP (for "Fuck the Pope"). According to the sociologist Robert Park, each separate part of the city is "stained with the peculiar sentiments of its population" (1968: 6). This applies in particular to Belfast, a place in which certain areas are clearly associated with specific political allegiances. Through the references to the omnipresent slogans on Belfast's wall, the author underlines the ethno-religious division of the city. Through the use of gloomy images, Costello paints a dark picture of the situation. Furthermore, she suggests that men from both ethno-religious sites are ready to lose their lives for a meaningless cause. Letting the "green" and "orange blood" metaphorically mingle, Costello attempts to draw attention to the absurdity of the fighting, as the ultimate result is not peace, but death.

In this context, the image of "blood" echoes the bleeding head of Annie's brother discussed previously. The allusion to "blood" refers to the protagonist's continuing trauma caused by the memory of her brother. According to Halbwachs, memories "occur in the form of systems" that means that over time they become connected to other memories (1992: 53). Consequently, the memory of one particular traumatic event triggers a whole network of traumatizing asso- 
ciations. In the same vein, Assmann argues that traumatizing pictures become engrained into the "landscape of the unconsciousness" so that they turn into an "internal 'vision' that takes on a life of its own." Thus, they cease to be "object[s] of observation" and become transformed into "agent[s] of haunting" (Assmann 1999: 217). In this sense, it could be argued that Annie's vision of her brother's split-open head turns into a haunting "mental picture." This very image reoccurs in Annie's above-mentioned retrospective description of Belfast through the allusion to "blood." The image becomes magnified so that it comes to stand for the political violence acted out on the city's streets. The “ceaseless rain" suggests a never-ending flow of blood, implicitly pointing at the brutal consequences of sectarian fighting. By referring to the "wake of the Titanic," Costello ends her book with the evocation of death and destruction. Through an apocalyptic image of Belfast, the author lays the blame for the persisting violence on both communities. Annie's adult voice, which stands in contrast to that of her as a teenager, lets the novel end on a tragic tone. This tone could be seen as the expression of the author's personal disillusionment about the conflict, which, in 1992, was far from over.

Our analysis has shown that Costello strives to address traumatizing historical events through the incorporation of verbally represented images into her literary text. The images become vivid in the novel by means of a narrative account rendered from the perspective of a teenage girl. Titanic Town sheds an innovative light on the clashes of the two ethno-religious communities through use of humor and the defamiliarizing perspective of a young girl. The author deploys the protagonist's traumatizing mental images in order to demonstrate Annie's perception of Belfast's urban space, her interpretation of what is seen as "normal life" in a warlike situation, as well as her cognitive images of certain traumatizing events. Thanks to the unusual point of view, Titanic Town gives rise to innovative readings of the Troubles, which differs from the adult's perspective from which the Northern Irish conflict is traditionally depicted. Titanic Town draws its readers into an intense engagement with the realities of the region's politics and intends to encourage them to adopt new ways of seeing life in Northern Ireland, which go well beyond established one-sided readings of the Troubles.

\section{Works cited}

Assmann, Aleida (1999) Cultural Memory and Western Civilisation (Cambridge: Cambridge University Press)

Bakhtin, Mikhail (1984) Rabelais and His World (Bloomington: Indiana University Press) 
Calame, Jon and Esther Charleworth (2009) Divided Cities: Belfast, Beirut, Jerusalem, Mostar, and Nicosia (Philadelphia: University of Pennsylvania Press)

Carroll, Noël (2014) Humour (Oxford: Oxford University Press)

Costello, Mary (1992) Titanic Town (London: Methuen)

Caterson, Simon (1994) “'Swimming from the Titanic': Mary Costello Talks to Simon

Caterson," Irish Studies Review, vol. 2, issue 8, pp. 6-8

Halbwachs, Maurice (1992) On Collective Memory. Ed. and trans. By Lewis A. Coser (Chicago: University of Chicago Press)

Heffernan, James A. W. (1993) Museum of Words. The Poetics of Ekphrasis from Homer to Ashbery (Chicago: University of Chicago Press)

Hurm, Gerd (1991) Fragmented Urban Images: The American City in Modern Fiction from Stephen Crane to Thomas Pynchon (Frankfurt: Peter Lang)

Kennedy, Liam (2003) Race and Urban Space in Contemporary American Literature (Edinburgh: Edinburgh University Press)

Kennedy-Andrews, Elmer (2003) (De-)Constructing the North: Fiction and the Northern Ireland Troubles Since 1969 (Dublin: Four Courts)

Kolk, Bessel Van der (2014) The Body Keeps the Score. Mind, Brain and Body in the Transformation of Trauma (London: Penguin)

Ley, David (1983) A Social Geography of the City (New York: Harper)

Lynch, Kevin (1960) The Image of the City (Cambridge, Massachusetts: M.I.T. Press)

Mercier, Vivian (1962) The Irish Comic Tradition (Oxford: Oxford University Press)

Mitchell, W. J. T. (2005) What do Pictures Want? The Lives and Loves of Images (Chicago: University of Chicago Press)

Mitchell, W. J. T. (2011) Cloning Terror. The War of Images, 9/11 to the Present (Chicago: University of Chicago Press)

Park, Robert (1968) "The City: Suggestions for the Investigation of Human Behaviour in the Urban Environment," in Robert Park and Ernest Burgess (eds.), The City (Chicago: The University of Chicago Press), pp. 1-46

Shirlow, Peter and Brendan Murtagh (2006) Belfast. Segregation, Violence and the City (Dublin: Pluto)

Shklovsky, Viktor (1965) “Art as Technique," in Lee T. Lemon and Marion J. Reis (eds.), Russian Formalist Criticism: Four Essays (Lincoln: University of Nebraska Press), pp. $9-24$

Stewart, Anthony T. Q. (1977) The Narrow Ground. Aspect of Ulster 1609-1969 (Belfast: The Black Staff)

Willet, Ralph (1995) The Naked City. Urban Crime Fiction in the US (Manchester: Manchester University Press)

\section{Online Sources}

"Interface Barriers, Peacelines and Defensive Architecture," 2017, <https://www.belfastinterfa ceproject.org/sites/default/files/publications/Interfaces\%20PDF.pdf> (accessed 11 September 2017) 
Kennedy, Maev, "The Trouble with Fictional Troubles" in The Guardian, 02 June 2005 <https:// www.theguardian.com/uk/2005/jun/02/hayfestival2005.northernireland> (accessed 13 November 2017)

Sutton, Malcolm, "An Index of Death from the Conflict in Ireland" <http://cain.ulst.ac.uk/sut ton/chron/index.html> (accessed 11 November 2017) 
